\title{
Sulindac activates NF-KB signaling in colon cancer cells
}

\author{
Dessislava Mladenova', Laurent Pangon ${ }^{1}$, Nicola Currey ${ }^{1}$, Irvin Ng${ }^{1}$, Elizabeth A Musgrove ${ }^{1,2}$, Shane T Grey $2,3+$ \\ and Maija RJ Kohonen-Corish ${ }^{1,2,4^{*}+}$
}

\begin{abstract}
Background: The non-steroidal anti-inflammatory drug (NSAID) sulindac has shown efficacy in preventing colorectal cancer. This potent anti-tumorigenic effect is mediated through multiple cellular pathways but is also accompanied by gastrointestinal side effects, such as colon inflammation. We have recently shown that sulindac can cause up-regulation of pro-inflammatory factors in the mouse colon mucosa. The aim of this study was to determine the signaling pathways that mediate the transcriptional activation of pro-inflammatory cytokines in colon cancer epithelial cells treated with sulindac sulfide.

Results: We found that sulindac sulfide increased NF-kB signaling in HCT-15, HCT116, SW480 and SW620 cells, although the level of induction varied between cell lines. The drug caused a decrease in $1 k B a$ levels and an increase of p65(RelA) binding to the NF-KB DNA response element. It induced expression of IL-8, ICAM1 and A20, which was inhibited by the NF-KB inhibitor PDTC. Sulindac sulfide also induced activation of the AP-1 transcription factor, which co-operated with NF-KB in up-regulating IL-8. Up-regulation of NF-KB genes was most prominent in conditions where only a subset of cells was undergoing apoptosis. In TNFa stimulated conditions the drug treatment inhibited phosphorylation on $1 \mathrm{KBa}$ (Ser 32) which is consistent with previous studies and indicates that sulindac sulfide can inhibit TNFa-induced NF-KB activation. Sulindac-induced upregulation of NF-KB target genes occurred early in the proximal colon of mice given a diet containing sulindac for one week.

Conclusions: This study shows for the first time that sulindac sulfide can induce pro-inflammatory NF-KB and AP-1 signaling as well as apoptosis in the same experimental conditions. Therefore, these results provide insights into the effect of sulindac on pro-inflammatory signaling pathways, as well as contribute to a better understanding of the mechanism of sulindac-induced gastrointestinal side effects.
\end{abstract}

Keywords: Pro-inflammatory cytokines, NF-kB, AP-1, IL-8, A20, Colon epithelial cells

\section{Background}

NSAIDs, including sulindac, have shown promising potential in colon cancer chemoprevention [1]. The chemopreventive potential of sulindac and other NSAIDs was initially attributed to COX inhibition, however, it is now recognized that the anti-proliferative and anti-inflammatory effects of sulindac can also be mediated through non-COX targets [2-5]. Sulindac sulfide is the pharmacologically active

\footnotetext{
* Correspondence: m.corish@garvan.org.au

tEqual contributors

'Kinghorn Cancer Centre, Garvan Institute of Medical Research, 370 Victoria

St, Darlinghurst, Sydney, NSW 2010, Australia

${ }^{2}$ St. Vincent's Clinical School, Faculty of Medicine, UNSW, Sydney, NSW,

Australia

Full list of author information is available at the end of the article
}

metabolite of sulindac, and is 5000 -fold more potent in inhibiting COX activity than the sulfone metabolite. It can also induce apoptosis in colon cancer cells at concentrations 4-5 times lower than those of the sulfone metabolite [6].

Long-term NSAID use is associated with gastrointestinal and cardiovascular side effects, including colon mucosal inflammation, which has also been reported in mice [7-9]. We have recently shown that apart from chemoprevention, long-term sulindac administration induces inflammatory lesions in the mouse colon, which show up-regulation of pro-inflammatory factors such as MIP-2 (the mouse homologue of IL-8) [9] and can progress to cancer in mice that are deficient for tumor suppressor genes. The mechanism by which sulindac can up-regulate pro-inflammatory

\section{Biomed Central}


genes is not known, but some of these genes are regulated by NF- $\kappa B$, whose activity is central to orchestrating the immune response [10]. This prompted us to investigate the molecular effects of sulindac sulfide on the NF- $\mathrm{B}$ pathway in vitro.

$\mathrm{NF}-\mathrm{kB}$ is the collective name for a family of transcription factors and is a major regulator of processes such as inflammation, cell survival and apoptosis. The NF-kB pathway can be activated by a large variety of factors, including cytokines and stress stimuli and NF- $\mathrm{kB}$ activation is central to the pathogenesis of chronic inflammatory disorders such as inflammatory bowel disease [11]. Cytokines and growth factors can also induce the activator protein-1 (AP-1) transcription factor, which regulates genes involved in numerous tumor-promoting functions as well as inflammatory processes [12].

NF- $\mathrm{kB}$ dimers function as a transcription factor in the nucleus and are sequestered in an inactive form in the cytoplasm, bound to Inhibitor of kappa B proteins (IкB), most often $\mathrm{I} \kappa \mathrm{B} \alpha$. Upon stimulation by pro-inflammatory cytokines, such as TNF $\alpha$ and IL-1, I kappa B kinase (IKK) is activated. IKK phosphorylates $I_{\kappa} B \alpha$, which is then degraded by the proteasome, allowing translocation of the NF- $\mathrm{kB}$ dimers to the nucleus. NF- $\mathrm{kB}$ signaling can be modulated by NSAIDs in experimental models but the exact mechanism is poorly understood $[13,14]$. Sulindac or its derivatives, sulindac sulfone and sulindac sulfide, were found to inhibit NF-kB activation in stimulated COS, human leukemic and human embryonic kidney cell lines $[14,15]$. However, sulindac and sulindac sulfide had no effect on NF-kB driven reporter gene expression in non-stimulated cells (basal levels of NF-kB activity) $[15,16]$. Subsequent studies in colon cancer cells found that aspirin, sulindac and sulindac sulfone inhibit NF-kB-dependent transcriptional activity and cause apoptosis, but this was shown to involve initial NF- $\mathrm{kB}$ pathway activation through $\mathrm{I} \kappa \mathrm{B} \alpha$ degradation and NF- $\mathrm{kB}$ nuclear translocation [17-19]. Therefore the effect of sulindac and its derivatives on NF- $\mathrm{BB}$ signaling may vary depending on the experimental conditions.

The aim of this study was to determine the signaling pathways leading to sulindac sulfide induced upregulation of IL- 8 and other pro-inflammatory mediators in the colon. IL- 8 was chosen because of the strong effect of sulindac on inducing MIP-2 (the mouse homologue of IL-8) in the mouse colon mucosa in our previous study, [9] while ICAM1 is considered to be a classic NF- $k B$ target [19]. A20 was chosen for this study because it is an early response NF-kB target gene, which is not known to be targeted by any other transcription factor. NF- $\mathrm{kB}$ activation is necessary for A20 transcription as IKK deficiency abolishes TNF $\alpha$-induced A20 transcription [20,21]. We have used COX-2 non-expressing or low-expressing cell lines in order to study COX-independent effects of sulindac sulfide. We provide evidence that sulindac sulfide can activate both NF- $\mathrm{kB}$ and AP-1 signaling pathways in the colon mucosa leading to upregulation of IL-8.

\section{Results}

Sulindac sulfide induces up-regulation of NF-кB target genes and concurrently induces cell death in HCT-15 colon cancer cells

As apoptosis induction is one of the well-established antitumorigenic mechanisms of sulindac sulfide [6] we first established a concentration that induces apoptosis in HCT15 cells. Sulindac sulfide treatment induced concentrationdependent cell death (Figure 1A). A concentration of $50 \mu \mathrm{M}$ significantly increased apoptotic cell death (4.7 fold \pm 0.6 SEM, $\mathrm{P} \leq 0.01$ ) while leaving the majority of the cell population viable at $4 \mathrm{~h}$. The higher concentration, $120 \mu \mathrm{M}$ sulindac sulfide also induced a significant increase in necrosis (2.6 fold $\pm 0.4 \mathrm{SEM}, \mathrm{P} \leq 0.02$ ) (Figure $1 \mathrm{~A}$ ). In addition the $120 \mu \mathrm{M}$ concentration caused a change in morphology - cell rounding and a swollen appearance, indicating toxicity with higher concentrations (Figure 1B).

It was previously shown that sulindac and sulindac sulfone decrease the protein level of NF-kB inhibitor I $\mathrm{BB} \alpha$ in colon cancer cells within 2-5 hours [19]. We next assessed the effect of sulindac sulfide on IкB $\alpha$. Treatment of HCT15 cells with $50 \mu \mathrm{M}$ and $120 \mu \mathrm{M}$ sulindac sulfide decreased $\mathrm{I} \kappa \mathrm{B} \alpha$ protein levels after 2 hours and $20 \mu \mathrm{M}, 50 \mu \mathrm{M}$ and $120 \mu \mathrm{M}$ after 4 hours of treatment (Figure 1C). The decrease in $\mathrm{IkB} \alpha$ was accompanied by an increase in mRNA expression of NF- $\mathrm{kB}$ target genes A20, ICAM1 and IL-8, which was more pronounced with 50 or $120 \mu \mathrm{M}$ sulindac sulfide (Figure 1D). Thus the $50 \mu \mathrm{M}$ concentration of sulindac sulfide could trigger apoptosis and proinflammatory gene up-regulation in the same experimental conditions.

In order to determine if this activation was transient or sustained, we studied the kinetics of $I_{\kappa} B \alpha$ degradation in cells treated with $50 \mu \mathrm{M}$ sulindac sulfide for $0.5,1,2,4$ and 16 hours. We observed a significant decrease of IkB $\alpha$ protein levels 2 hours post treatment $(\mathrm{P}<0.05)$ and this was sustained until the conclusion of the experiment at 16 hours (Figure 1E). This was not due to decreased transcription as $50 \mu \mathrm{M}$ sulindac sulfide actually increased IkB $\alpha$ mRNA transcripts by 3.3 fold ( \pm 1.14 SEM) 4 hours post-treatment compared to control-treated cells, which is consistent with NF- $\mathrm{kB}$ pathway activation where increased transcription of $\mathrm{I} \kappa \mathrm{B} \alpha$ is an early response.

\section{Sulindac sulfide-induced pro-inflammatory gene up- regulation is dependent on NF-KB activity but is not mediated by apoptosis}

NF- $\mathrm{kB}$ is most commonly composed of p50 and p65(RelA) heterodimers, of which only p65 has transactivation potential [22]. We tested whether sulindac sulfide increases 


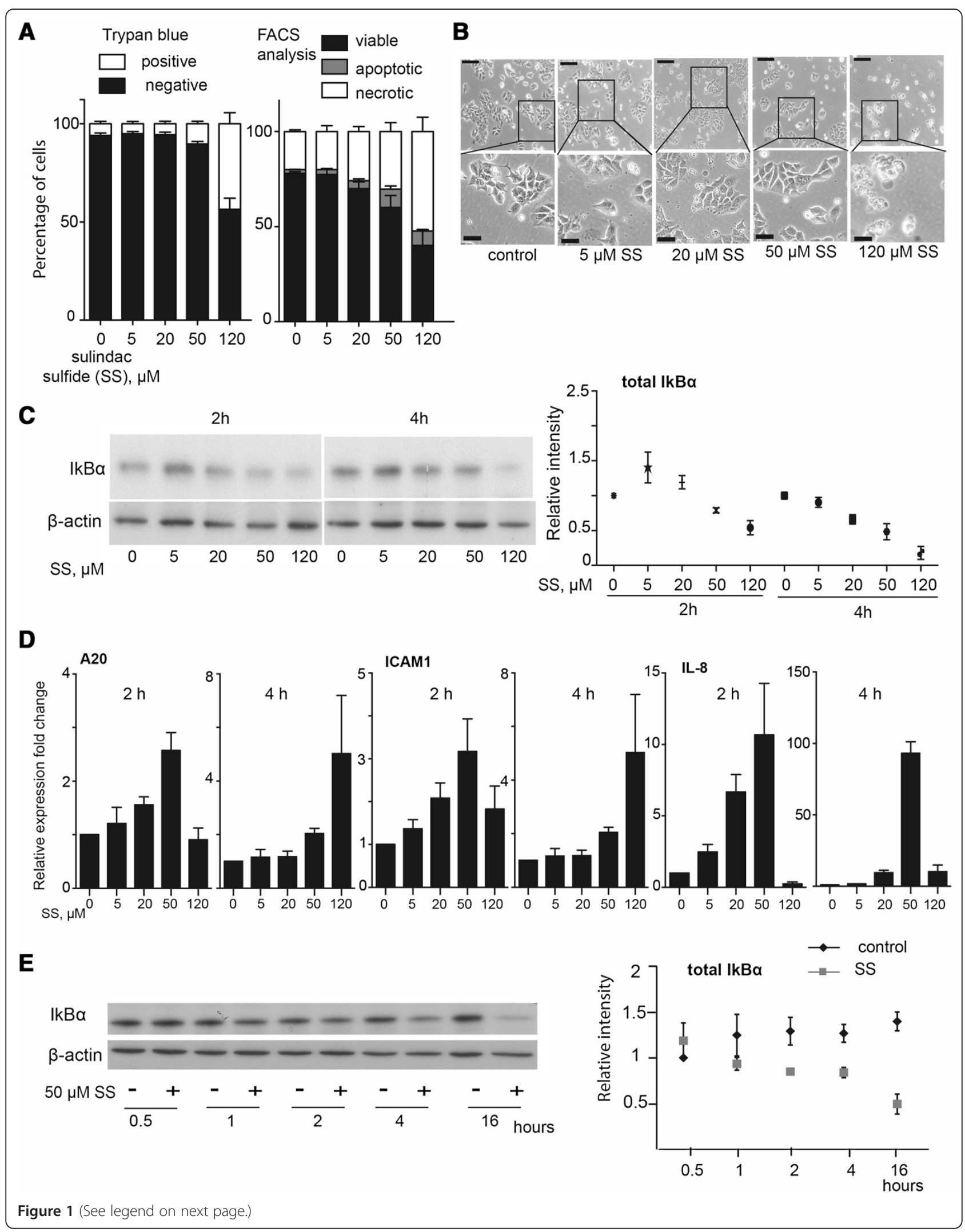


(See figure on previous page.)

Figure 1 Sulindac sulfide induces activation of the NF-кB pathway and increases cell death. (A) Quantification of apoptosis and necrosis of sulindac sulfide (SS) treated cells (4 hours), assessed by trypan blue exclusion assay or FACS analysis of Annexin-V-Fluos/PI stained cells. Bars represent mean percentage of cells in each population \pm SEM $(n=3-4)$. (B) Photomicrographs of HCT-15 cells treated with sulindac sulfide for 8 hours (phase-contrast, scale bars $60 \mu \mathrm{m}$ and insert $24 \mu \mathrm{m}$ ). (C) HCT-15 cells were treated with the indicated doses of sulindac sulfide or the control DMSO (equivalent to the highest dose SS) for 2 and 4 hours, after which lysates were collected and western blot analysis was performed for $1 \mathrm{kBa}$ and the loading control $\beta$-actin. Densitometry of IkBa levels normalized to $\beta$-actin. Error bars represent SEM ( $\mathrm{n}=3$-4). (D) $q \mathrm{PCR}$ analysis for A20, ICAM1 and IL-8 mRNA expression. HCT-15 cells were treated with the indicated concentrations of SS or the control. Gene expression was normalized to the house-keeping gene GAPDH. The data are presented as fold change \pm SEM (from 3 independent experiments). (E) Western blot for I KBa levels in cells treated with SS or the control for the indicated time points. Densitometry of IkBa levels normalized to $\beta$-actin. Error bars represent SEM.

the binding of p65 to the NF-kB DNA response element. HCT-15 cells were treated with sulindac sulfide and/or TNF $\alpha$ and nuclear lysates were prepared. A colorimetric p65 transcription factor assay was used to assess the amount of nuclear p65 bound to the consensus NF$\kappa \mathrm{B}$ response element immobilized on the assay plate (Figure 2A). Both sulindac sulfide alone and TNF $\alpha$ alone significantly increased p65 binding to DNA $(\mathrm{P}<0.01)$.

In order to test whether sulindac sulfide-induced proinflammatory gene up-regulation is dependent on NF-kB activity, we treated cells with the NF- $\mathrm{B}$ specific inhibitor PDTC [23]. Pre-treatment of cells with $50 \mu \mathrm{M}$ PDTC effectively inhibited both TNF $\alpha$-induced and sulindac sulfide-induced up-regulation of the NF- $\mathrm{kB}$ target genes A20, ICAM-1 and IL-8 (Figure 2B). Concurrent treatment of cells with PDTC and sulindac sulfide also reduced the proportion of viable cells (Figure $2 \mathrm{C}$ ). Thus PDTC potentiated sulindac sulfide-induced cancer cell death.

Cells undergoing cell death can release pro-inflammatory molecules such as high mobility group box 1 protein (HMGB1) that can induce NF-kB signaling cascade [24]. Therefore, we next tested whether sulindac sulfide-induced apoptotic response is involved in NF- $\mathrm{kB}$ activation. In order to inhibit sulindac sulfide-induced apoptosis, we pretreated cells with the irreversible caspase inhibitor Q$\mathrm{VD}-\mathrm{OPh}$, a broad-spectrum caspase inhibitor with very low cytotoxicity which is also known to inhibit HMGB1 release [25]. We assessed NF- $k B$ activation by qPCR for the NF- $k B$ target genes A20, ICAM-1 and IL-8 in the presence or absence of the caspase inhibitor. Q-VD-OPh effectively inhibited sulindac sulfide-induced apoptosis, assessed by western blot analysis for cleaved caspase 3 (Figure 2D). NF$\mathrm{\kappa B}$ target genes were significantly up-regulated in cells cotreated with sulindac sulfide and Q-VD-OPh compared to control treated cells and cells treated with the caspase inhibitor alone (Figure 2E). Therefore these data suggest that sulindac sulfide-induced NF-kB activation is not mediated by the apoptotic response, triggered by the drug.

\section{Sulindac treatment of mice induces pro-inflammatory genes within one week}

We previously reported that sulindac up-regulates proinflammatory genes in the proximal colon of mice treated with sulindac for 20 weeks [9]. These mice had developed pronounced mucosal damage and transmural inflammatory response caused by the drug. Therefore, we investigated mice treated with sulindac for 1 week in order to assess the effect of sulindac on gene expression at an early time point prior to the development of major tissue damage [9]. We selected NF- $\mathrm{kB}$ target genes previously implicated in colon pathogenesis [26-28], and analyzed their expression in colon mucosal tissue from control and sulindac treated mice. While the proinflammatory genes Cox-2, iNOS, MIP-2, IL- $1 \beta$ and cFos were significantly up-regulated by the sulindac diet $(P \leq 0.01)$ in the proximal colon, there was no significant change in ICAM1, A20 or c-Jun gene expression (Figure 3). This confirms the effect of sulindac on inducing pro-inflammatory gene expression in vivo but suggests different dynamics or selectivity of sulindacinduced NF- $\mathrm{kB}$ target genes in vivo.

\section{Sulindac sulfide treatment induces up-regulation of NF-кB target genes in HCT116, SW480 and SW620 cells}

In order to assess whether sulindac sulfide can activate the NF-kB pathway in the background of a variety of molecular defects, we selected three additional colorectal cancer cell lines, HCT116, SW480 and SW620. NF-kB pathway activation was assessed by a western blot analysis for $\mathrm{I} \kappa \mathrm{B} \alpha$ total levels and NF- $\mathrm{kB}$ target gene expression (Figure 4A, B, C). Up-regulation of NF- $\mathrm{B}$ target genes A20, ICAM1 and IL-8 was observed in SW480 and SW620 cells following stimulation with sulindac sulfide but only A20 and IL-8 were strongly upregulated in HCT116 cells (Figure 4C). Furthermore, there was variation in $\mathrm{I} \kappa \mathrm{B} \alpha$ levels following the drug treatment. The decrease in $\mathrm{I} \kappa \mathrm{B} \alpha$ levels in response to sulindac sulfide treatment was the most pronounced in HCT116 cells but no significant changes were observed in SW620 cells. Nevertheless, mRNA levels of ICAM1 did not significantly increase in HCT116 cells except in cells treated with $120 \mu \mathrm{M}$ sulindac sulfide for 4 hours, in contrast to the strong response seen in HCT-15, SW480 and SW620 cells. This suggests that in addition to NF-kB other factors may be modulating sulindacinduced up-regulation of pro-inflammatory cytokines. 
AP-1 as well as NF-KB transcription factors are involved in sulindac-sulfide induced activation of IL-8 gene

expression

Strong up-regulation of mRNA levels for the IL-8 gene was observed in all four cell lines tested (Figures 1D, 4C). IL-8 gene expression levels are known to be strikingly variable, ranging from not detectable levels to over 100fold activation depending on the inducing stimuli [29].
The core IL- 8 promoter contains a NF- $\mathrm{kB}$ element as well as activating protein (AP)-1 and CAAT/enhancer-binding protein (C/EBP)-binding sites [29]. Unlike the NF-kB binding sites, the AP-1 and C/EBP sites are not essential for IL-8 induction but are required for maximum gene expression in some cell types (reviewed in [29]).

We hypothesized that the strong expression of IL-8 gene following sulindac sulfide treatment may be due to

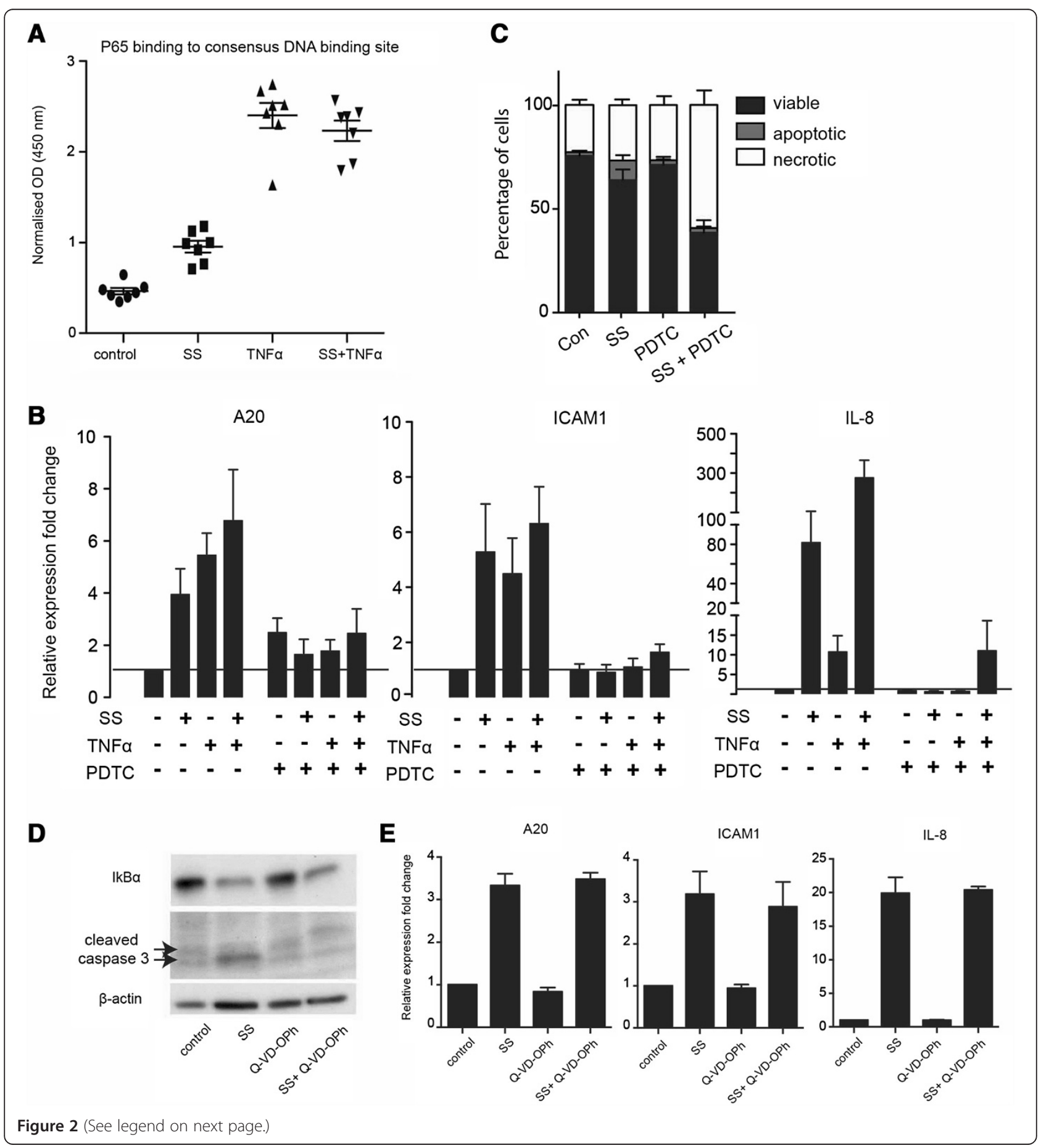


(See figure on previous page.)

Figure 2 Sulindac sulfide-induced pro-inflammatory gene up-regulation is dependent on NF-KB activity but is not mediated by apoptosis. (A) Colorimetric assay of p65 DNA binding activity to NF-KB response element in nuclear lysates of HCT-15 cells. Cells were treated with the control or SS for 4 hours and where indicated $10 \mathrm{ng} / \mathrm{ml}$ TNFa was added for the last 40 minutes before cell lysis. The DNA-binding activity of p65 is expressed as the optical density at $450 \mathrm{~nm}$. Error bars indicate SEM. (B) qPCR analysis for A20, IL-8 and ICAM-1 mRNA expression levels. HCT-15 cells were pretreated with or without $50 \mu \mathrm{M}$ PDTC for 1.5 hours, followed by treatment with the control (DMSO), $50 \mu \mathrm{M}$ sulindac sulfide (SS), $10 \mathrm{ng} / \mathrm{ml}$ TNFa or both in combination for 4 hours. Bars represent fold change of relative gene expression, normalized to the housekeeping gene GAPDH. Mean values \pm SEM (from 3 to 4 independent experiments). (C) Quantification of apoptosis and necrosis of cells treated with $50 \mu \mathrm{M}$ SS, PDTC or both compounds in combination for 4 hours, assessed by FACS analysis of Annexin-V-Fluos/PI stained cells. Bars represent mean percentage of cells in each population \pm SEM $(n=3)$. (D) HCT-15 cells were pre-treated with $20 \mu M$ pan-caspase inhibitor Q-VD-OPh or the control DMSO for 1 hour and then stimulated with $50 \mu \mathrm{M}$ sulindac sulfide (SS) or the vehicle DMSO (control) for 2 hours A western blot analysis for cleaved caspase $3(17 / 19 \mathrm{kDa})$ and the house-keeping gene $\beta$-actin. (E) qPCR analysis for A20, ICAM1 and IL-8 in cells treated with the indicated concentrations of SS in the presence or absence of Q-VD-Oph for 2 hours. The data are presented as fold change \pm SEM (from 3 independent experiments).

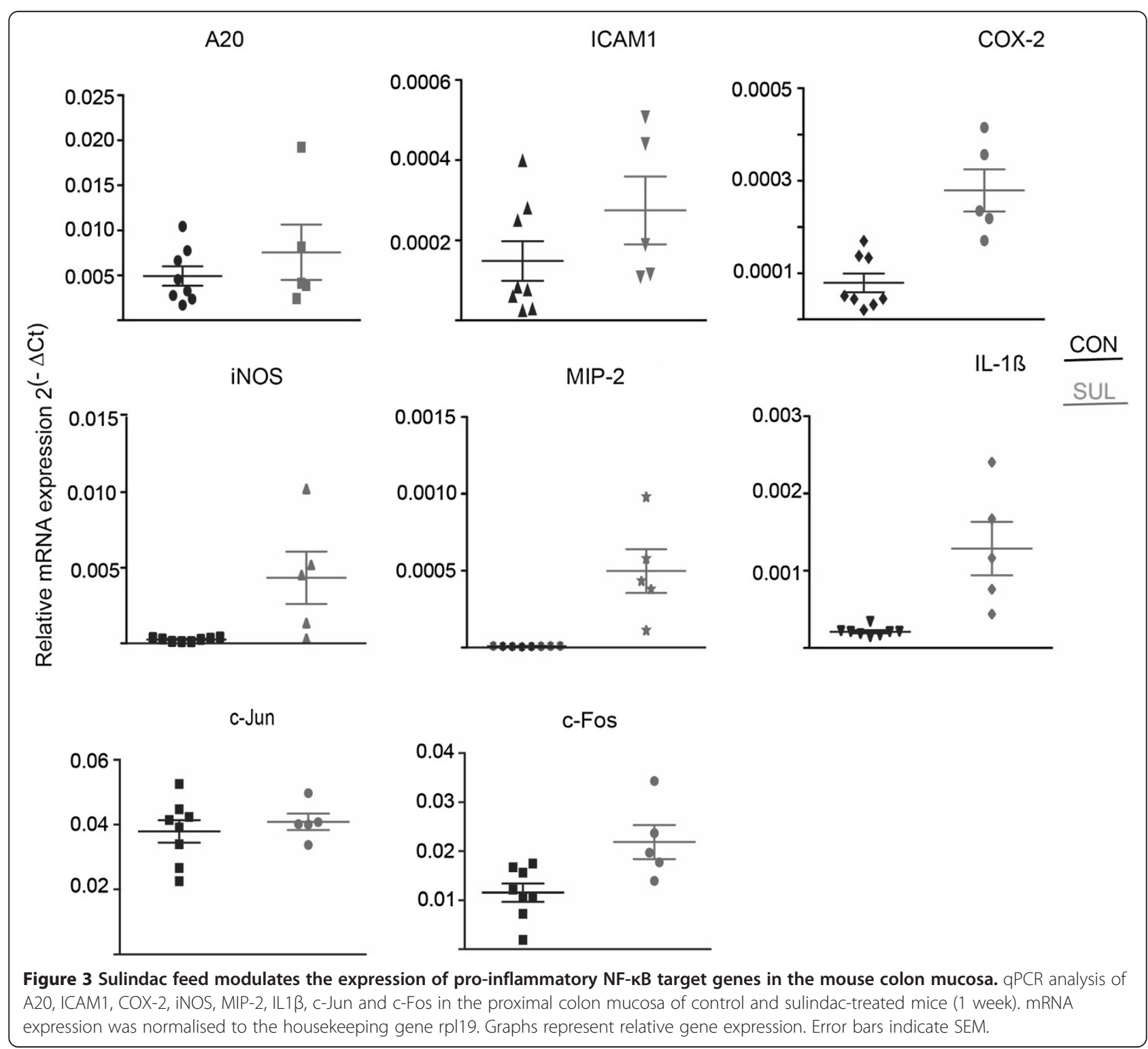




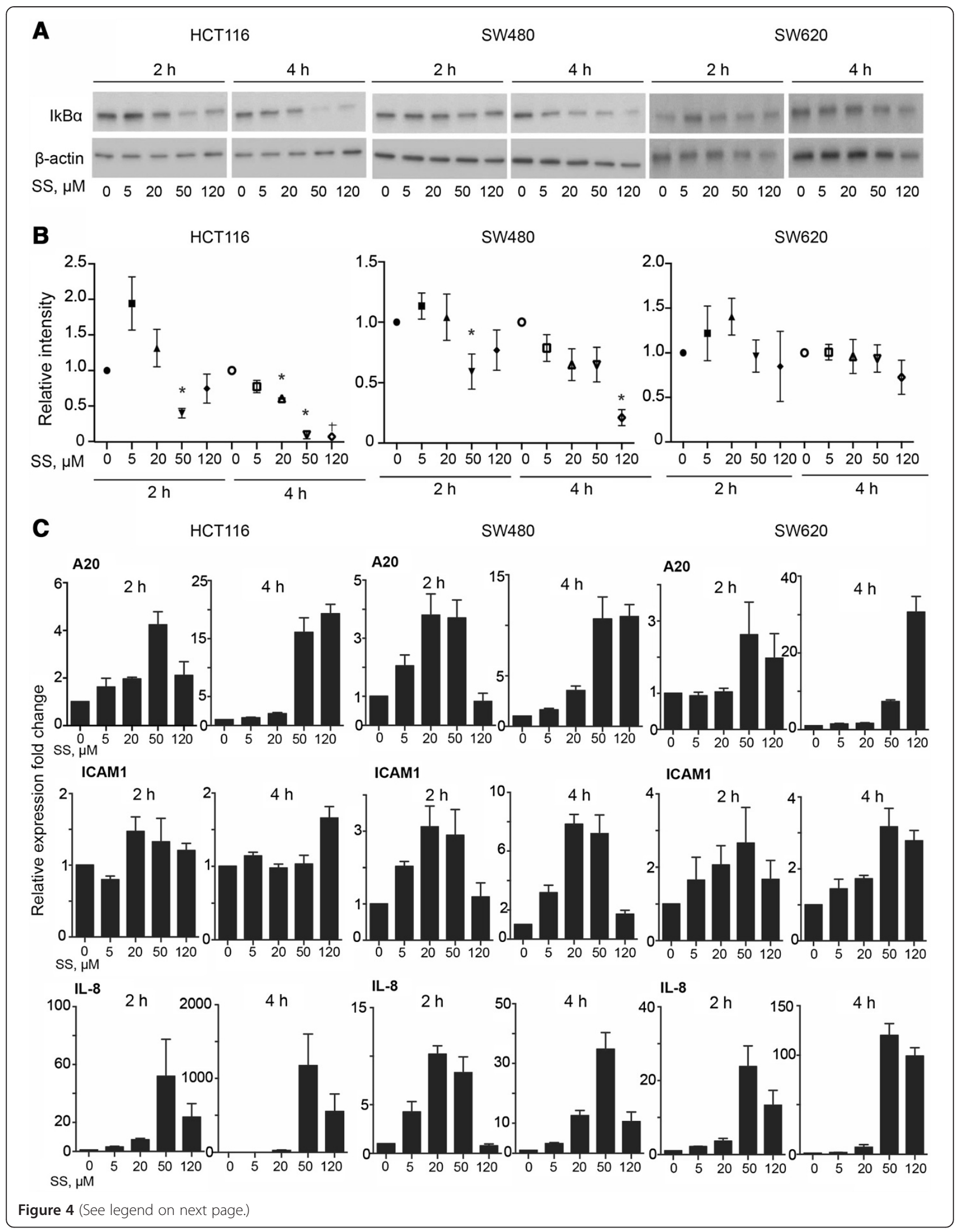


(See figure on previous page.)

Figure 4 Sulindac sulfide treatment induces up-regulation of NF-KB target genes in HCT116, SW480 and SW620 cells. (A) HCT116, SW480 and SW620 cells were treated with the indicated doses of sulindac sulfide (SS) or the control DMSO (equivalent to the highest dose SS) for 2 and 4 hours, after which lysates were collected and western blot analysis was performed for IkBa and the loading control $\beta$-actin. (B) Densitometry of IKBa levels normalized to $\beta$-actin. Error bars represent SEM $(n=3) .{ }^{*}$ represents $P<0.05$, + average from two data points. (C) GPCR analysis for A20, ICAM1 and IL-8 mRNA expression. Gene expression was normalized to the house-keeping gene GAPDH. The data are presented as fold change \pm SEM (from 3 independent experiments).

activation of both NF-kB and AP-1 transcription factors. AP-1 is a transcription factor composed of homo or heterodimers of the Jun, Fos and ATF family members [30]. We studied the nuclear and cytoplasmic protein levels of the NF-kB subunit p65 and the AP-1 members c-Fos and c-Jun in control and sulindac sulfide-treated cells (Figure 5A). Treatment with sulindac sulfide increased the amount of nuclear p65, associated with a decrease in cytoplasmic p65 levels, indicative of p65 nuclear translocation following the drug treatment (Figure 5A). The levels of total c-Jun and c-Fos were up-regulated in both the cytoplasmic and nuclear fraction upon sulindac sulfide treatment and there was a marked increase in phosphorylated c-Jun and JunD indicative of activation of the JNK pathway [31]. In consensus with the western blot results, the mRNA expression levels of c-JUN and c-FOS were markedly upregulated in the presence of 50 and $120 \mu \mathrm{M}$ sulindac sulfide and cFOS levels also increased following treatment with $20 \mu \mathrm{M}$ sulindac sulfide for 4 hours (Figure 5B).

Next we assessed whether both transcription factors are required for the strong up-regulation of IL-8 gene expression using an IL-8 promoter construct cloned in a luciferase reporter vector, with or without mutated NF-kB and AP-1 binding sites (Figure 5C). Treatment with TNF $\alpha$ was used as a positive control and resulted in a strong increase in luciferase activity, which was slightly down-regulated in cells transfected with the AP-1 mutant binding sites but completely abolished in cells transfected with mutated NF- $\mathrm{KB}$ binding sites (Figure 5C). In contrast, in sulindac sulfide-treated cells both the mutated AP-1 and NF- $\kappa B$ binding sites strongly reduced the up-regulation in luciferase activity $(\mathrm{P}<0.05)$ (Figure 5C). These results indicate that the strong upregulation of IL-8 gene expression induced by sulindac sulfide treatment is dependent on both the NF- $\kappa B$ and AP-1 transcription factors, whereas TNF $\alpha$ up-regulates IL-8 mainly through NF- $\mathrm{kB}$.

\section{Sulindac sulfide modulates TNFa-induced ІкBa phosphorylation and degradation}

Since sulindac sulfide caused a decrease in IкB $\alpha$ protein levels in basal conditions, and induced up-regulation of NF- $\mathrm{kB}$ target genes, we next tested the effect of sulindac

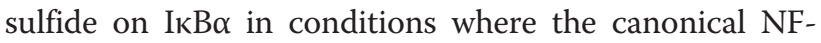
$\mathrm{\kappa B}$ pathway is activated through stimulation by the cytokine TNF $\alpha$. Upon stimulation with TNF $\alpha$, NF-кB activation is preceded by rapid IkB $\alpha$ phosphorylation on serine 32 and 36 residues by the Inhibitor of kappa $B$ Kinase (IKK) complex [32], leading to its proteosomemediated degradation. We analyzed the kinetics of IкB $\alpha$ phosphorylation and degradation in sulindac sulfide and TNF $\alpha$-treated cells.

HCT-15 cells were pre-treated with $50 \mu \mathrm{M}$ sulindac sulfide for 2 hours and then stimulated with TNF $\alpha$ for $15 \mathrm{~min}$ to 3 hours. Western blot analysis of ІкB $\alpha$ showed that sulindac sulfide pre-treatment in the absence of TNF $\alpha$ did not increase I $\mathrm{KB} \alpha$ phosphorylation on Ser32, whereas TNF $\alpha$ stimulation induced rapid IкB $\alpha$ phosphorylation on Ser32. However, in cells pre-treated with sulindac sulfide, TNF $\alpha$-induced І $к B \alpha$ phosphorylation was less pronounced (Figure 6A, B). TNF $\alpha$ caused a gradual decrease in overall I $\mathrm{I} B \alpha$ protein abundance, which reached its lowest point 40 minutes after stimulation and returned to normal levels 3 hours following TNF $\alpha$ treatment. Sulindac sulfide pre-treatment caused a decrease in IKB $\alpha$ protein levels at 2 hours posttreatment and there was little change in $I_{\kappa} B \alpha$ intensity upon subsequent stimulation with TNFa (Figure 6A, C).

In summary, sulindac sulfide treatment reduced the total levels of IKB $\alpha$ in unstimulated cells, suggesting activation of the NF-kB pathway, but with a slower kinetics compared to TNFa. In contrast, sulindac sulfide treatment appeared to inhibit TNF $\alpha$-induced phosphorylation on IkB $\alpha$ (Ser 32) which is consistent with previous studies [14]. These results imply that sulindac sulfide inhibits TNFo-induced NF-kB activation at a level upstream of IкB $\alpha$ degradation.

\section{Sulindac sulfide promotes up-regulation of the NF-KB target gene A20}

To further explore the effects of sulindac sulfide on the NF-kB pathway in basal and TNF $\alpha$ stimulated cells, we studied the expression of the early response NF- $\mathrm{KB}$ target gene TNFAIP3 (A20), which is not known to be targeted by any other transcription factor. NF- $\mathrm{kB}$ activation is necessary for A20 transcription as IKK deficiency abolishes TNFo-induced A20 transcription [20,21]. HCT-15 cells were treated with sulindac sulfide alone, TNF $\alpha$ alone, or both compounds in combination for 1 to 4 hours (Figure 7A). Both sulindac sulfide and TNF $\alpha$, as well as the combination of the two, increased A20 mRNA levels compared to cells treated with the control. The 


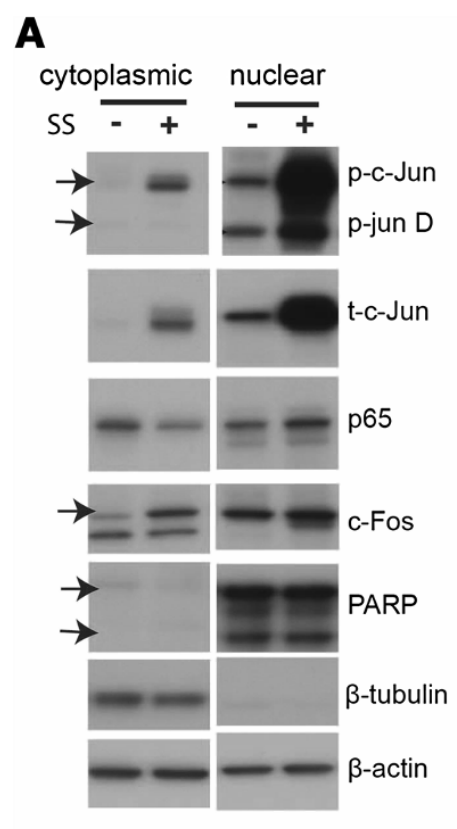

\section{B}
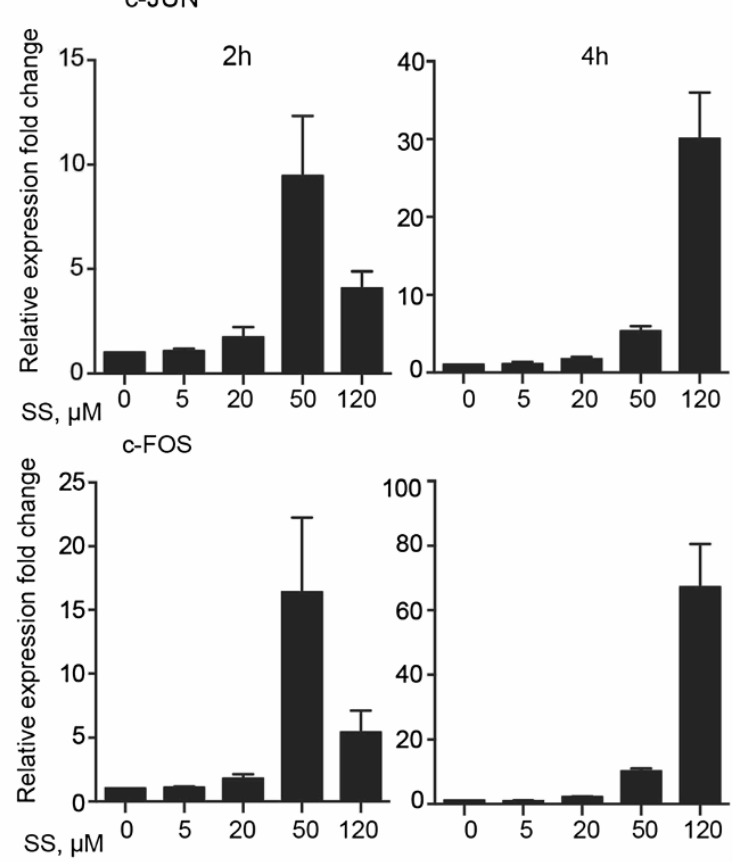

\section{C}

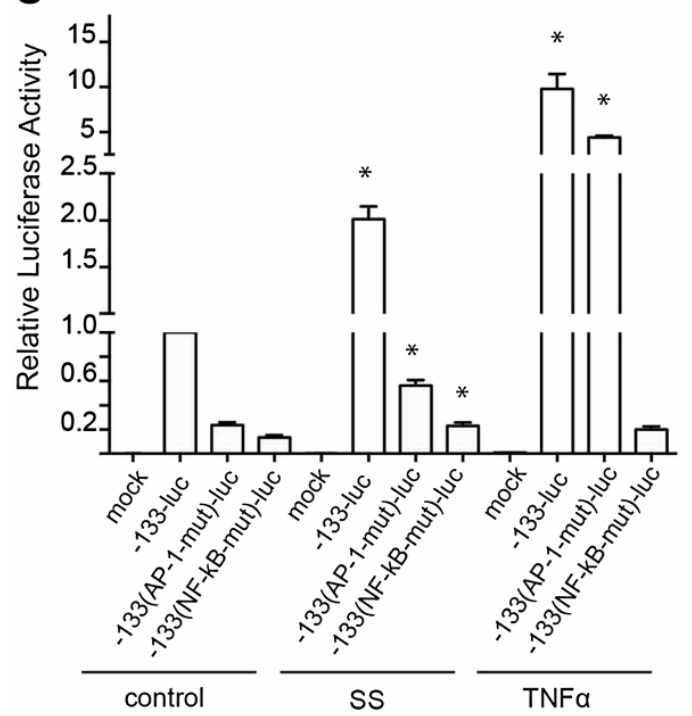

Figure 5 AP-1 and NF-KB transcription factors are involved in sulindac-sulfide induced activation of IL-8 gene expression. (A) HCT-15 cells were treated with $50 \mu \mathrm{M}$ sulindac sulfide (SS) or the control DMSO for 4 hours. Western blot analysis of the cytoplasmic and nuclear fraction for phosphorylated c-Jun (and phosphorylated junD), c-Jun, c-Fos and p65. PARP is used as a nuclear marker while $\beta$-tubulin is used as a cytoplasmic marker. Loading control $\beta$-actin. Representative blot of two independent experiments. (B) qPCR analysis for c-JUN and c-FOS. Bars represent fold change of relative gene expression, normalized to the house-keeping gene GAPDH. Mean values \pm SEM (from three independent experiments). (C) Luciferase reporter gene assay was performed to measure transcriptional activity from the human endogenous IL-8 promoter. HCT-15 cells were transfected with the IL-8 promoter reporter (-133-luc) or reporters with mutated AP-1 and NF-KB binding sites (-133(AP-1mut)-luc and -133(NF-KB-mut)-luc respectively) and $\beta$-glactosidase reporter and treated with $20 \mu \mathrm{M}$ sulindac sulfide (SS), the vehicle control DMSO (control) or the positive control TNFa $(20 \mathrm{ng} / \mathrm{ml})$ for 2 hours. Luciferase activity was normalized to $\beta$-galactosidase activity and is presented as mean Relative Luciferase Activity \pm SEM (from three independent experiments performed in duplicate). * represents $\mathrm{P}<0.05$. 

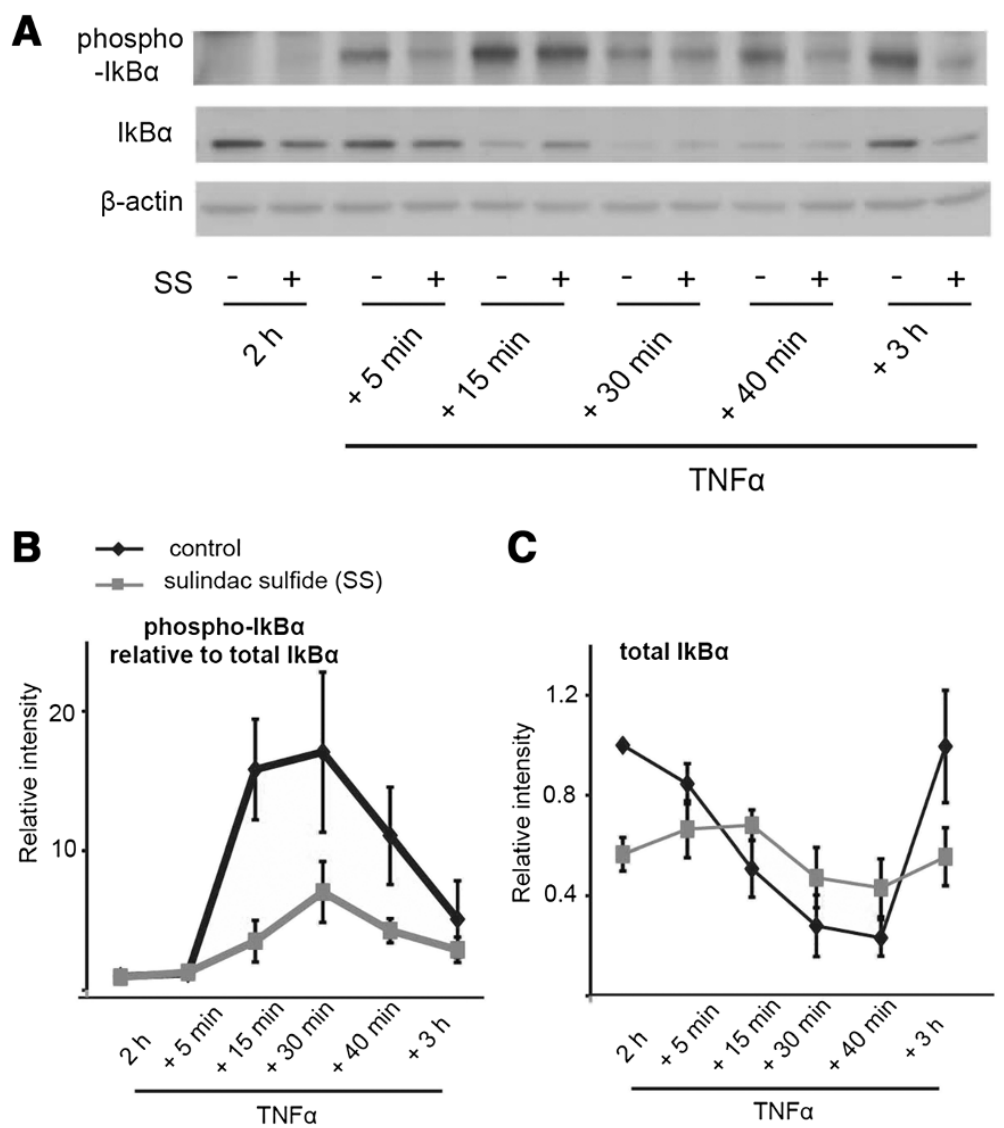

Figure 6 Sulindac sulfide modulates TNFa-induced IкBa phosphorylation and degradation. HCT-15 cells were treated with sulindac sulfide or the vehicle DMSO (control) for 2 hours. TNFa $(10 \mathrm{ng} / \mathrm{ml})$ was added to culture media for the indicated periods and cell lysates were prepared. (A) Western blot analysis for phosphorylated IkBa (Ser32), total IkBa and $\beta$-actin. Representative blot from four independent experiments. (B) Graph representing the intensity of phosphorylated IKBa, normalized to total IKBa and $\beta$-actin \pm SEM. (C) Graph representing the intensity of IKBa, normalized to $\beta$-actin \pm SEM.

combination of sulindac sulfide and TNFa did not result in a sustained increase in A20 mRNA levels more than that of TNF $\alpha$ treatment alone (Figure 7A). Taken together these results imply that sulindac sulfide does not synergise with TNF $\alpha$ or inhibit TNF $\alpha$-induced A20 mRNA expression.

In order to test whether sulindac sulfide-induced A20 up-regulation is transcriptionally dependent, cells were pretreated with the transcription inhibitor actinomycin D. As expected actinomycin D reduced A20 mRNA expression in cells stimulated with TNF $\alpha$, confirming that the selected dose of $1 \mu \mathrm{M}$ actinomycin D inhibits gene transcription. Sulindac sulfide also failed to up-regulate A20 mRNA expression in the presence of actinomycin D compared to vehicle control cells (Figure 7B). This result is consistent with a mechanism of sulindac sulfide-induced up-regulation of A20 mRNA that is dependent on transcriptional activation.

\section{Discussion}

The NSAID sulindac has shown promising potential in colon cancer chemoprevention. However, serious concerns about gastrointestinal and cardiovascular side effects, including colon inflammation, perforation and bleeding, limit the clinical use of NSAIDs. We recently reported that long-term use of dietary sulindac can cause localized inflammation in the mouse proximal colon and that the inflammatory lesions are characterized by expression of pro-inflammatory NF-kB target genes [9]. This led us to explore the molecular effects of sulindac sulfide on the NF-kB pathway in vitro, a pathway implicated in both inflammation and malignancy. This study shows for the first time that sulindac sulfide can induce NF-kB and AP-1 mediated pro-inflammatory gene expression as well as trigger cancer cell death in the same experimental conditions. These findings may have implications for understanding the mechanism of NSAID-induced colon damage and inflammation.

Sulindac sulfide-induced up-regulation of NF-kB target genes was detected in four colorectal cancer cell lines, HCT-15, HCT-116, SW480 and SW620 as well as in the mucosa of mouse proximal colon one week after the start 

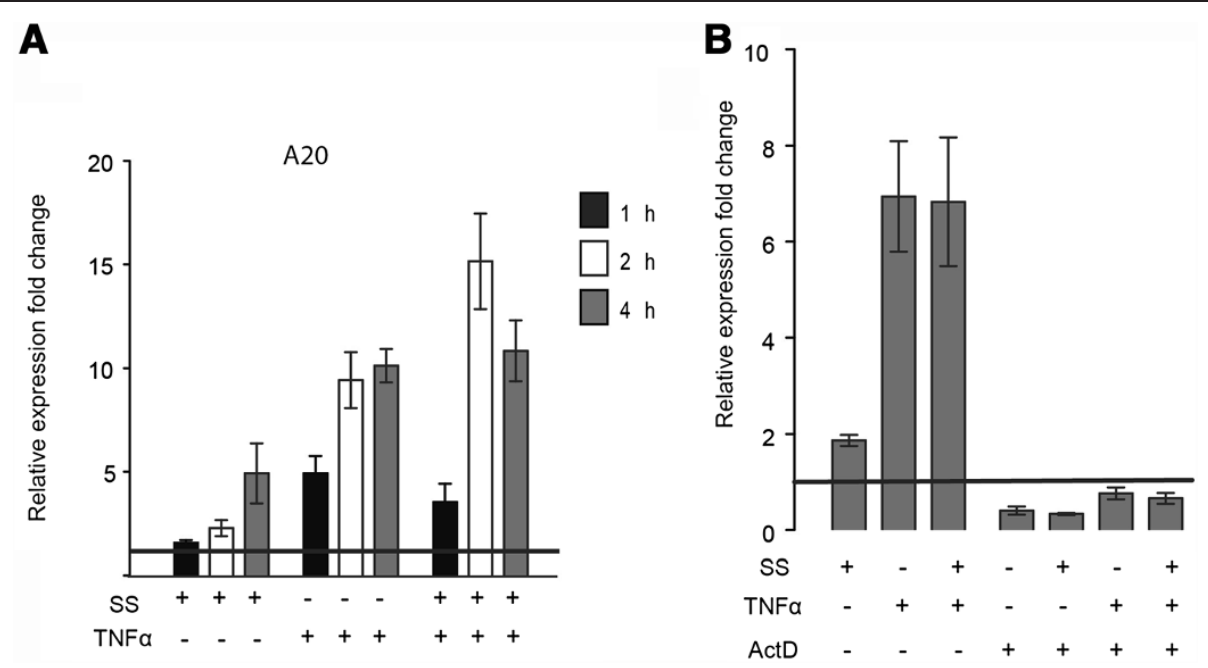

Figure 7 Sulindac sulfide induces transcriptionally-dependent up-regulation of A20 mRNA levels. qPCR analysis for A20 mRNA expression. HCT-15 cells were treated with $50 \mu \mathrm{M}$ sulindac sulfide (SS), the vehicle DMSO (control line) or $10 \mathrm{ng} / \mathrm{ml}$ TNFa for the indicated time points. A20 gene expression was normalized to the house-keeping gene GAPDH. The data are presented as fold change \pm SEM (from 4 to 7 independent experiments). (A) Cells were treated with the control, SS, TNFa or both in combination for the indicated time points. (B) Cells were pre-treated with $1 \mu \mathrm{M}$ actinomycin D (ActD) and then treated with the indicated compounds for 4 hours.

of sulindac diet. Sulindac sulfide treatment also resulted in transcriptional and translational up-regulation of the AP-1 transcription factor components c-FOS and c-JUN, accompanied by an increase in nuclear accumulation of p65, c-Fos and c-Jun.

The strongest up-regulation was seen for the chemokine IL-8, both in vivo (the murine homologue MIP-2) and in vitro (IL-8) [9]. IL-8 plays a key role in promoting proliferation and survival of endothelial and cancer cells, angiogenesis and neutrophil infiltration [11,33]. IL-8 was the single most differentially expressed gene among 6000 significantly expressed genes in gastric epithelial cell line in response to Helicobacter pylori exposure [34]. Cooperation between $\mathrm{AP}-1$ and NF- $\mathrm{BB}$ is required for optimal IL-8 gene induction in virus infected airway epithelium [35]. In order to assess whether NF- $\mathrm{kB}$ and AP1 cooperation was required for the up-regulation of IL-8 mRNA levels in HCT-15 cells, we used the IL-8 promoter element cloned into a luciferase reporter construct with wild type or mutated NF- $\mathrm{kB}$ and AP-1 binding sites. Mutation of either NF- $\mathrm{KB}$ or AP-1 binding sites diminished the luciferase activity upon sulindac sulfide stimulation, whereas mutation of the AP-1 binding site had less effect after TNF $\alpha$ stimulation. These results indicate that the strong up-regulation of IL- 8 gene expression induced by sulindac sulfide treatment is dependent on both the NF-kB and AP-1 transcription factors, whereas TNF $\alpha$ up-regulates IL-8 mainly through NF-kB. In agreement with this study, it has been reported that treatment of acute myeloid leukemia (AML) cell lines or bone marrow cells from AML patients with sulindac sulfide increases the expression of AP-1 family transcription factors [31]. AP-1 transcription factor is involved in the regulation of many cytokine genes and is therefore an important component of the inflammatory response [36]. Furthermore it has been suggested that NF- $\mathrm{KB}$ can modulate AP-1 activity, raising the intriguing possibility that the interplay by the two transcription factors can fine-tune the inflammatory response [37].

Treatment of mice for 1 week with sulindac also resulted in significant up-regulation of other NF-kB target genes IL$1 \beta$, iNOS and Cox- 2 as well as c-Fos in the colon mucosa. This suggests that sulindac induces an early strong immunogenic response in the mouse colon. However, in contrast to sulindac sulfide treatment in vitro there was no significant change in ICAM-1 or A20 gene expression. This is consistent with our previous findings in mice treated with sulindac for 20 weeks [9], Although A20 is a target of NF$\mathrm{\kappa B}$, it is actually suppressed in inflammatory bowel disorders, where NF- $\mathrm{kB}$ is activated. A20 is a part of the negative feedback loop of NF- $\mathrm{kB}$ signaling and A20 deregulation in inflammatory disorders is consistent with its role as an anti-inflammatory factor [38]. For example, A20 is downregulated in Crohn's disease and enterocyte-specific deficiency of A20 in mice results in increased susceptibility to experimental colitis [28,39]. This highlights the complex microenvironment in the colon inflamed tissue, where cross-talk between inflammatory and colon epithelial cells further modulates gene expression.

$\mathrm{NF}-\mathrm{kB}$ also regulates the transcription of $\mathrm{TNF} \alpha$ and we have previously shown that sulindac sulfide induces 
TNF $\alpha$ expression [9]. It is possible that sulindac sulfideinduced TNF $\alpha$ acts in an autocrine manner to activate the NF- $\mathrm{KB}$ pathway. TNF $\alpha$-mediated NF- $\mathrm{kB}$ activation can lead to cell survival or cell death depending on the metabolic context of the cell and the contribution of other signalling pathways such as AKT activation and the JNK signalling cascade [40-42]. Although TNF $\alpha$ was initially associated with tumour necrosis [43], mounting evidence suggests that TNF $\alpha$ plays a role in tumour growth and progression [44], induction of genes involved in inflammation, tissue repair [45] and angiogenesis [46]. Thus sulindac sulfide-induced activation of the NF- $k B$ pathway may result in a positive feedback loop through induction of TNF $\alpha$ and may contribute to the proinflammatory or anti-tumorigenic activity of the drug depending on the cellular context.

NF- $\mathrm{kB}$ is known to exert pro-survival signals, but here we show that sulindac sulfide induces cell death at a concentration that also activates NF-kB. The most prominent activation of $\mathrm{NF}-\mathrm{kB}$ target genes was seen with concentration $(50 \mu \mathrm{M})$ of the drug that left the majority of cells viable. In some conditions molecules released during the apoptotic response can activate the NF- $\kappa B$ pathway. However, here sulindac sulfide treatment resulted in NF- $\mathrm{KB}$ activation in the presence or absence of the pan-caspase inhibitor Q-VD-Oph, which effectively inhibits apoptosis, indicating that the druginduced NF- $\mathrm{KB}$ activity is not a consequence of sulindacinduced apoptosis. Our experiments do not exclude the involvement of NF- $\mathrm{kB}$ in sulindac sulfide-induced apoptosis. Under certain stimuli NF- $\mathrm{kB}$ activity may lead to cell death [47] but sulindac also activates NF-kB-independent pro-apoptotic pathways. Interestingly, suppression of NF$\mathrm{\kappa B}$ activity with the inhibitor PDTC potentiated sulindac sulfide-induced cell death by necrosis. PDTC use in the clinic for the treatment of colon cancer has been supported by a number of studies and there are reports of PDTC enhancing the anti-cancer potential of 5-fluorouracil (5-FU) [48]. As PDTC potentiates sulindac sulfide-induced cancer cell death while inhibiting sulindac-sulfide-induced upregulation of pro-inflammatory factors, it is possible that the combination of PDTC and sulindac may be further explored as a relevant therapeutic option for colorectal cancer.

A previous report has suggested that sulindac sulfide inhibits the NF- $\mathrm{kB}$ pathway but the experimental conditions were different from our study and IL-8, A20 and ICAM1 gene expression was not analyzed [14]. Sulindac sulfide inhibited NF- $\kappa B$-inducible kinase (NIK)-induced IKK $\beta$ kinase activity in COS cells, but at a concentration that was four times higher than used here. In the same study this inhibition was not seen with the $40 \mu \mathrm{M}$ concentration of sulindac sulfide [14]. IKK $\beta$ is an essential kinase upstream of $\mathrm{I} \kappa \mathrm{B} \alpha$, crucial for the activation of
NF- $\mathrm{kB}$ through the canonical pathway. Also, in another study sulindac sulfide administered at doses higher than $50 \mu \mathrm{M}$ inhibited IKK $\beta$ activity and NF-kB DNA binding activity in HCT116 colon cancer cells [49]. This implies that the inhibitory effect of sulindac sulfide on the NF- $\kappa$ B pathway may be concentration dependent.

Although this study is the first to report an activating role of the NSAID sulindac sulfide on the NF- $\kappa B$ pathway, celecoxib, a COX-2 selective NSAID was previously shown to have similar effects on NF-kB signaling both in vitro and in vivo. At $50 \mu \mathrm{M}$ celecoxib resulted in an increase in IL- $1 \beta$-induced NF- $\mathrm{BB}$ DNA binding activity and NF-kB-dependent gene expression, although in another study celecoxib was found to have an inhibitory role on NF- $\mathrm{BB}$ activity $[15,50]$. Similarly, the COX-2 selective NSAID NS-398 induced an increase in NF- $\mathrm{kB}$ DNA binding activity but not in NF-kB-reporter gene expression in colon cancer cells while indomethacin, a drug closely related to sulindac, was reported to induce gastropathy through activation of $\mathrm{NF}-\mathrm{kB}$ in gastric microvascular endothelial cells [51,52]. Further studies are necessary to determine if other NSAIDs activate the $\mathrm{NF}-\kappa \mathrm{B}$ pathway.

\section{Conclusions}

In summary, this study provides experimental evidence that the pharmacologically-active sulindac metabolite, sulindac sulfide, activates NF- $\mathrm{kB}$-mediated endogenous gene transcription in colon cells, including NF- $\kappa B$ target pro-inflammatory factors in vitro and in vivo. This is the first report to show that sulindac sulfide activates both NF- $\mathrm{kB}$ and AP-1 transcription factors, which may be important in NSAID-induced gastrointestinal toxicity [53-56] and the increased risk of acute myocardial infarction in patients receiving some NSAIDs [57]. These results imply that some of the adverse effects caused by sulindac in the mouse colon such as inflammation and ulceration may be caused by aberrant immunoregulation in the colon mucosa. Further studies are required to address sulindac activation of $\mathrm{NF}-\mathrm{kB}$ in vivo and whether this is responsible for the side effects of NSAIDs in the human colon.

\section{Methods}

\section{Tissue culture and reagents}

HCT-15, HCT116 and SW620 cells (CCL-225, CCL-247, CCL-227; ATCC, USA) were propagated in RPMI 1640 $\left(\mathrm{GIBCO}^{\circledR}\right.$, Invitrogen Corporation) supplemented with $10 \%$ fetal bovine serum (FBS) (Hyclone Laboratories Inc., Australia), HEPES (10 mM, GIBCO $\left.{ }^{\circledR}\right)$, glutamine (4 mM, GIBCO $\left.{ }^{\circledR}\right)$, insulin $(10 \mu \mathrm{g} / \mathrm{ml}$, Actrapid, Novo Nordisk, Australia) and gentamycin $(20 \mu \mathrm{g} / \mathrm{ml}$, Pfizer, Australia), except as noted. SW620 cells were propagated in RPMI $1640\left(\mathrm{GIBCO}^{\circledR}\right)$ with $10 \% \mathrm{FBS}$ and $20 \mu \mathrm{g} / \mathrm{ml}$ 
gentamycin. For experiments cells were plated at $2 \times 10^{5}$ cells/well in 6-well culture plate (Corning) and cells were incubated overnight in reduced serum conditions $(0.2 \%$ FBS) prior to treatment with the indicated reagents. The cell lines were authenticated by CellBank Australia in 2011 using an Identifiler PCR Amplification Kit (Applied Biosystems, USA). Tumor necrosis factor $\alpha$ (TNF $\alpha)$ was obtained from Peprotech Inc., (USA); sulindac sulfide, PDTC, actinomycin D and DMSO from Sigma-Aldrich (MO, USA); Q-VD-OPh from MP Biomedicals (USA). Sulindac sulfide, actinomycin D and Q-VD-OPh were dissolved in DMSO while PDTC was dissolved in distilled water.

\section{Mice and sulindac diet}

Mice on the $\mathrm{C} 57 \mathrm{Bl} / 6 \mathrm{~J}$ background were bred in specific pathogen free conditions. Mice ( 6 weeks old) were given a diet containing 320 p.p.m. sulindac (Sigma-Aldrich; Specialty Feeds, Australia) for 1 week or control feed ad libitum. The diet was standard mouse cubes. This study was carried out in accordance with the recommendations of the National Health and Medical Research Council (Australian Code of Practice for the Care and Use of Animals for Scientific Purposes). All animal experiments were approved by the Garvan Institute of Medical Research Animal Ethics Committee (protocol no. 10/40).

\section{mRNA and protein analysis}

The mucosal surface of the proximal colonic tissue was lightly scraped and snap frozen in liquid nitrogen for RNA extraction. RNA from mouse tissue or cell lines was extracted using Qiagen RNeasy mini (QIAGEN $\mathrm{GmbH}$, Germany). Q-PCR reactions were performed using SYBRgreen, (Applied Biosystems, USA), Taqman (Applied Biosystems, USA) or UPL assays (Roche Applied Science) on ABI Prism 7900-HT Real Time PCR system (Applied Biosystems) or the Roche Lightcycler 480 (Roche Applied Science). For protein analysis cell lysates [58] were separated on polyacrylamide gels (10-15\%) and transferred to polyvinylidene difluoride (PVDF) membranes. The membranes were blocked with $5 \%(\mathrm{w} / \mathrm{v})$ bovine serum albumin, dissolved in $0.2 \%(\mathrm{v} / \mathrm{v})$ Tween $20 /$ trisbuffered saline (TBS). The membranes were incubated with primary antibodies for $1 \mathrm{~h}$ RT or overnight at $4^{\circ} \mathrm{C}$ ( $\beta$-actin, 1:10 000, clone AC15, Sigma; IкB $\alpha$ \#242, 1:1000; Phospho-IкB $\alpha$ (Ser32) \#2859 14D4; cleaved caspase 3 (Asp175) \#9661, Phospho-c-Jun (Ser73) \#9164, c-Jun \#9165 (Cell Signalling Technology Inc., USA), c-Fos ab7963, beta-tubulin ab6046 (Abcam, UK), p65 (A) sc-109 (Santa Cruz Biotechnology Inc., USA). ImageJ densitometry software (National Institutes of Health, USA) or Quantity One software (Bio-Rad Laboratories, Canada) were used for gel band quantitative densitometric analysis.

\section{Nuclear/cytoplasmic fractionation}

Cells were plated at $32.575 \times 10^{5}$ cells in $150 \times 20 \mathrm{~mm}$ Petri dish (Corning) and cells were incubated overnight in reduced serum conditions $(0.2 \% \mathrm{FBS})$ prior to treatment with sulindac sulfide. Cells were lysed with Cayman nuclear extraction kit No10009277 (Cayman Chemicals, USA) according to the manufacturer's instructions. Lysates were resolved on $10 \%$ polyacrylamide gels and transferred to polyvinylidene difluoride (PVDF) membranes.

\section{P65(RelA) DNA-binding assay}

P65 binding was assessed using Cayman's p65 transcription factor assay (Cayman Chemicals, USA). A double-stranded oligonucleotide that contained a consensus p65 binding site was immobilized in all plate wells and incubated with previously prepared flash frozen nuclear extracts $(7.5 \mu \mathrm{g} /$ well $)$ overnight at $4^{\circ} \mathrm{C}$ without shaking. The plate was washed extensively according to manufacturer's instructions and incubated with a primary anti-p65 antibody, followed by a secondary antibody conjugated with horseradish peroxidase (HRP) that was used for detection. The absorbance is expressed as the optical density at $450 \mathrm{~nm}$, normalized to the background readings. Positive and negative controls were included in the assay kit.

\section{Detection of apoptosis \\ Trypan blue exclusion assay}

After the indicated treatments, cells floating in the media and trypsinized adherent cells were collected. Cells were incubated in 1:1 ratio with $0.4 \%$ Trypan blue (GIBCO) and were counted under a phase contrast microscope or using the Countess ${ }^{\mathrm{TM}}$ automated cell counter (Invitrogen). Cells with compromised membrane integrity are positive for trypan blue and were represented as a percentage of total counted cells.

\section{Flow cytometry analysis for AnnexinV/propidium iodide}

Apoptosis was detected by dual staining for phosphatidylserine (PS) externalization (AnnexinV-fluorescent isothiocyanate-conjugated Fluos) and propidium iodide (PI) cell incorporation by flow cytometry (BD FACSCanto ${ }^{\text {тM }}$ flow cytometer) using the Annexin-V-Fluos staining kit (Roche Applied Science) according to the manufacturer's instructions. Briefly, after treatment and trypsinization, adherent and detached cells from different treatment groups were counted and incubated for $15 \mathrm{~min}$ at $15-25^{\circ} \mathrm{C}$ with Annexin-V-Fluos labeling solution. PS externalization is a specific marker of early apoptotic events while PI is taken only by cells with compromised cell membrane (necrosis). Cells were considered apoptotic when they were Annexin-V-positive and PI-negative and necrotic when they were Annexin$\mathrm{V}$ - and PI- positive or Annexin-V-negative and PIpositive. Appropriate electronic compensation of the 
instrument was used in order to exclude overlapping of the two emission spectra.

\section{Luciferase reporter assay for IL-8 expression}

Cells $\left(2 \times 10^{5} /\right.$ well $)$ were plated into a 6 -well plate, in duplicate for each treatment group. Transfection for every well was performed with $0.1 \mu \mathrm{g} \beta$-galactosidase internal control plasmid (pEF-DEST51lacZ) and $0.8 \mu \mathrm{g}$ IL-8 promoter luciferase reporter constructs [59]. Transfection was performed in 10\% FCS media, using $3 \mu \mathrm{l} /$ well $\mathrm{X}$ tremeGene HP DNA transfection reagent (Roche) following the manufacturer's instructions. After stimulation, adherent cells were lysed in lysis buffer (Galacto-Star ${ }^{\mathrm{rm}}$ System, T2071-0607049, Tropix ${ }^{\circledR}$, USA) on ice. The supernatant was used for the luciferase assay. Samples (from each well of cultured cells) were pipetted in duplicate into a 96-well luminometer plate (OptiPlate ${ }^{\mathrm{Tm}}-96,6005290$, PerkinElmer ${ }^{\circledR}$, Zaventem, Belgium). $\beta$-galactosidase activity was determined by addition of freshly diluted Galacto$\mathrm{Star}^{\mathrm{Tm}}$ reagent, following an incubation for $30 \mathrm{~min}$ at RT. Plates were read using the FLUOstar OPTIMA microplate reader (BMG LABTECH GmbH, Germany) with a luminescence optic reader configuration and automatic reagent injection. Luciferase activity was determined by addition of freshly diluted luciferine (Luciferase Assay System, Cat \#E1501, Promega, USA) to the lysates and the plates were read immediately as above. Control for transfection efficiency in each well from the multi-well culture plate was obtained by assessing the $\beta$-galactosidase activity of the lysate for that well. Relative luciferase activity for a sample was determined by dividing the average luciferase activity by the relative amount of $\beta$-galactosidase activity.

The reporter constructs were a kind gift by Professor Naofumi Mukaida, Cancer Research Institute, Kanazawa University Kakuma-machi, Japan [59]. The constructs used contained the 5 ' region of the IL-8 gene spanning downstream from $-133 \mathrm{bp}$ with wild type or mutated AP-1 and NF- $\mathrm{kB}$ sites. This region contains three cis elements, AP-1 (2126 to $2120 \mathrm{bp}$ ), NF-IL-6-like (member of the C/EBP family) (294 to $281 \mathrm{bp}$ ), and $\mathrm{kB}$-like ( 280 to $270 \mathrm{bp}$ ) sites [59]. The constructs were named: -133-luc; -133(NF-kBmut)-luc; -133(AP-1-mut)-luc.

\section{Statistical analysis}

The data are graphed as mean \pm SEM from at least 3 independent experiments. Student $t$ test was used for comparisons between two groups. A P value of $<0.05$ was considered significant.

\section{Abbreviations}

A20: Zinc finger protein A20; AP-1: Activator protein-1; COX: Cyclooxygenase; HMGB1: High mobility group box 1 protein; ICAM1: Intercellular adhesion molecule 1; IKBa: Inhibitor of kappa B alpha; IKK: I kappa B kinase; IL-8: Interleukin 8; MIP-2: Macrophage inflammatory protein 2; NF-kB: Nuclear factor kappa B; NSAID: Non-steroidal anti-inflammatory drug; PDTC: Pyrrolidine dithiocarbamate; Q-VD-OPh: (3S)-5-(2,6-Difluorophenoxy)-3-[[(2S)-3-methyl-1-oxo- 2-[(2-quinolinylcarbonyl)amino]butyl]amino]-4-oxo-pentanoic acid hydrate; SS: sulindac sulfide; TNFa: Tumor necrosis factor alpha.

\section{Competing interests}

The authors declare that they have no competing interests.

\section{Authors' contributions}

DM designed and conducted most experiments, analyzed the data and wrote the manuscript. DM, MKC and SG conceived the project and wrote the manuscript. NC, LP and IN designed and conducted experiments, and analyzed the data. EAM provided valuable advice throughout the study and helped writing the manuscript. All authors read and approved the final version of the manuscript.

\section{Acknowledgments}

We thank Prof Naofumi Mukaida, Kanazawa University Kakuma-machi, Japan, for supplying the AP-1 and NF-KB reporter vectors and A/Prof John Silke, Walter and Eliza Hall Institute, Melbourne, Australia, for his expert advice on the experiments. Funding was provided by the National Health and Medical Research Council of Australia, Cancer Institute NSW, Cure Cancer Australia and Cancer Australia. DM was supported by a Cancer Institute NSW Research Scholar Award and an Australian Postgraduate Award. STG is an Australian Research Council Future Fellow.

\section{Author details}

${ }^{1}$ Kinghorn Cancer Centre, Garvan Institute of Medical Research, 370 Victoria St, Darlinghurst, Sydney, NSW 2010, Australia. ${ }^{2}$ St. Vincent's Clinical School, Faculty of Medicine, UNSW, Sydney, NSW, Australia. ${ }^{3}$ Immunology Research Program, Garvan Institute of Medical Research, Sydney, NSW, Australia.

${ }^{4}$ School of Medicine, University of Western Sydney, Sydney, Australia.

Received: 6 August 2013 Accepted: 25 September 2013

Published: 1 October 2013

\section{References}

1. Meyskens FL Jr, McLaren CE, Pelot D, Fujikawa-Brooks S, Carpenter PM Hawk E, Kelloff G, Lawson MJ, Kidao J, McCracken J, et al: Difluoromethylornithine plus sulindac for the prevention of sporadic colorectal adenomas: a randomized placebo-controlled, double-blind trial. Cancer Prev Res (Phila Pa) 2008, 1:32-38.

2. Tegeder I, Pfeilschifter J, Geisslinger G: Cyclooxygenase-independent actions of cyclooxygenase inhibitors. FASEB J 2001, 15:2057-2072.

3. Piazza GA, Alberts DS, Hixson $\sqcup$, Paranka NS, Li H, Finn T, Bogert C, Guillen JM, Brendel K, Gross PH, et al: Sulindac sulfone inhibits azoxymethane-induced colon carcinogenesis in rats without reducing prostaglandin levels. Cancer Res 1997, 57:2909-2915.

4. Baek SJ, Kim KS, Nixon JB, Wilson LC, Eling TE: Cyclooxygenase inhibitors regulate the expression of a TGF-beta superfamily member that has proapoptotic and antitumorigenic activities. Mol Pharmacol 2001, 59:901-908

5. Baek SJ, Wilson LC, Lee CH, Eling TE: Dual function of nonsteroidal antiinflammatory drugs (NSAIDs): inhibition of cyclooxygenase and induction of NSAID-activated gene. J Pharmacol Exp Ther 2002, 301:1126-1131.

6. Piazza GA, Rahm AK, Finn TS, Fryer BH, Li H, Stoumen AL, Pamukcu R, Ahnen DJ: Apoptosis primarily accounts for the growth-inhibitory properties of sulindac metabolites and involves a mechanism that is independent of cyclooxygenase inhibition, cell cycle arrest, and p53 induction. Cancer Res 1997, 57:2452-2459.

7. Thiefin $\mathrm{G}$, Beaugerie $\mathrm{L}$ : Toxic effects of nonsteroidal antiinflammatory drugs on the small bowel, colon, and rectum. Joint Bone Spine 2005, 72:286-294.

8. Itano O, Yang K, Fan K, Kurihara N, Shinozaki H, Abe S, Jin B, Gravaghi C, Edelmann W, Augenlicht $L$, et al: Sulindac effects on inflammation and tumorigenesis in the intestine of mice with Apc and Mlh1 mutations. Carcinogenesis 2009, 30:1923-1926.

9. Mladenova D, Daniel JJ, Dahlstrom JE, Bean E, Gupta R, Pickford R, Currey N, Musgrove EA, Kohonen-Corish MR: The NSAID sulindac is chemopreventive in the mouse distal colon but carcinogenic in the proximal colon. Gut 2011, 60:350-360. 
10. Karin M, Greten FR: NF-kappaB: linking inflammation and immunity to cancer development and progression. Nat Rev Immunol 2005, 5:749-759.

11. Mladenova D, Kohonen-Corish MR: Mouse Models of Inflammatory Bowel Disease - Insights into the Mechanisms of Inflammation-associated Colorectal Cancer. In Vivo 2012, 26:627-646

12. Terzic J, Grivennikov S, Karin E, Karin M: Inflammation and colon cancer. Gastroenterology 2010, 138:2101-2114. e2105.

13. Ulrich CM, Bigler J, Potter JD: Non-steroidal anti-inflammatory drugs for cancer prevention: promise, perils and pharmacogenetics. Nat Rev Cancer 2006, 6:130-140.

14. Yamamoto Y, Yin MJ, Lin KM, Gaynor RB: Sulindac inhibits activation of the NF-kappaB pathway. J Biol Chem 1999, 274:27307-27314

15. Takada Y, Bhardwaj A, Potdar P, Aggarwal BB: Nonsteroidal antiinflammatory agents differ in their ability to suppress NF-kappaB activation, inhibition of expression of cyclooxygenase-2 and cyclin D1, and abrogation of tumor cell proliferation. Oncogene 2004, 23:9247-9258.

16. Wick M, Hurteau G, Dessev C, Chan D, Geraci MW, Winn RA, Heasley LE, Nemenoff RA: Peroxisome proliferator-activated receptor-gamma is a target of nonsteroidal anti-inflammatory drugs mediating cyclooxygenase-independent inhibition of lung cancer cell growth. $\mathrm{Mol}$ Pharmacol 2002, 62:1207-1214.

17. Stark LA, Din FV, Zwacka RM, Dunlop MG: Aspirin-induced activation of the NF-kappaB signaling pathway: a novel mechanism for aspirinmediated apoptosis in colon cancer cells. Faseb J 2001, 15:1273-1275.

18. Stark LA, Dunlop MG: Nucleolar sequestration of RelA (p65) regulates NFkappaB-driven transcription and apoptosis. Mol Cell Biol 2005, 25:5985-6004

19. Loveridge CJ, MacDonald AD, Thoms HC, Dunlop MG, Stark LA: The proapoptotic effects of sulindac, sulindac sulfone and indomethacin are mediated by nucleolar translocation of the RelA(p65) subunit of NF-kappaB. Oncogene 2008, 27:2648-2655.

20. Cooper JT, Stroka DM, Brostjan C, Palmetshofer A, Bach FH, Ferran C: A20 blocks endothelial cell activation through a NF-kappaB-dependent mechanism. J Biol Chem 1996, 271:18068-18073.

21. Laherty CD, Hu HM, Opipari AW, Wang F, Dixit VM: The Epstein-Barr virus LMP1 gene product induces A20 zinc finger protein expression by activating nuclear factor kappa B. J Biol Chem 1992, 267:24157-24160.

22. Schmitz ML, Baeuerle PA: The p65 subunit is responsible for the strong transcription activating potential of NF-kappa B. EMBO J 1991, 10:3805-3817

23. Schreck R, Meier B, Mannel DN, Droge W, Baeuerle PA: Dithiocarbamates as potent inhibitors of nuclear factor kappa $B$ activation in intact cells. J Exp Med 1992, 175:1181-1194.

24. Guo ZS, Liu Z, Bartlett DL, Tang D, Lotze MT: Life after death: targeting high mobility group box 1 in emergent cancer therapies. Am J Cancer Res 2013, 3:1-20.

25. Caserta TM, Smith AN, Gultice AD, Reedy MA, Brown TL: Q-VD-OPh, a broad spectrum caspase inhibitor with potent antiapoptotic properties. Apoptosis 2003, 8:345-352.

26. Lee EG, Boone DL, Chai S, Libby SL, Chien M, Lodolce JP, Ma A: Failure to regulate TNF-induced NF-kappaB and cell death responses in A20deficient mice. Science 2000, 289:2350-2354.

27. Shah YM, Ito S, Morimura K, Chen C, Yim SH, Haase VH, Gonzalez FJ: Hypoxia-inducible factor augments experimental colitis through an MIFdependent inflammatory signaling cascade. Gastroenterology 2008, 134:2036-2048. 2048 e2031-2033.

28. Vereecke L, Sze M, Mc Guire C, Rogiers B, Chu Y, Schmidt-Supprian M, Pasparakis M, Beyaert R, van Loo G: Enterocyte-specific A20 deficiency sensitizes to tumor necrosis factor-induced toxicity and experimental colitis. J Exp Med 2010, 207:1513-1523.

29. Hoffmann E, Dittrich-Breiholz O, Holtmann H, Kracht M: Multiple control of interleukin-8 gene expression. J Leukoc Biol 2002, 72:847-855.

30. Mechta-Grigoriou F, Gerald D, Yaniv M: The mammalian Jun proteins: redundancy and specificity. Oncogene 2001, 20:2378-2389.

31. Singh R, Cadeddu RP, Frobel J, Wilk CM, Bruns I, Zerbini LF, Prenzel T, Hartwig S, Brunnert D, Schroeder T, et al: The non-steroidal antiinflammatory drugs Sulindac sulfide and Diclofenac induce apoptosis and differentiation in human acute myeloid leukemia cells through an AP-1 dependent pathway. Apoptosis 2011, 16:889-901.

32. DiDonato JA, Hayakawa M, Rothwarf DM, Zandi E, Karin M: A cytokineresponsive lkappaB kinase that activates the transcription factor NFkappaB. Nature 1997, 388:548-554.
33. Lee YS, Choi I, Ning Y, Kim NY, Khatchadourian V, Yang D, Chung HK, Choi D, LaBonte MJ, Ladner RD, et al: Interleukin-8 and its receptor CXCR2 in the tumour microenvironment promote colon cancer growth, progression and metastasis. Br J Cancer 2012, 106:1833-1841.

34. Eftang LL, Esbensen $Y$, Tannaes TM, Bukholm IR, Bukholm G: Interleukin-8 is the single most up-regulated gene in whole genome profiling of H. pylori exposed gastric epithelial cells. BMC Microbiol 2012, 12:9.

35. Mastronarde JG, Monick MM, Mukaida N, Matsushima K, Hunninghake GW: Activator protein-1 is the preferred transcription factor for cooperative interaction with nuclear factor-kappaB in respiratory syncytial virusinduced interleukin-8 gene expression in airway epithelium. J Infect Dis 1998, 177:1275-1281.

36. Johnson GL, Lapadat R: Mitogen-activated protein kinase pathways mediated by ERK, JNK, and p38 protein kinases. Science 2002, 298:1911-1912.

37. Fujioka S, Niu J, Schmidt C, Sclabas GM, Peng B, Uwagawa T, Li Z, Evans DB, Abbruzzese JL, Chiao PJ: NF-kappaB and AP-1 connection: mechanism of NF-kappaB-dependent regulation of AP-1 activity. Mol Cell Biol 2004 24:7806-7819.

38. Kelly C, Shields MD, Elborn JS, Schock BC: A20 regulation of nuclear factorkappaB: perspectives for inflammatory lung disease. Am J Respir Cell Mol Biol 2011, 44:743-748.

39. Arsenescu R, Bruno ME, Rogier EW, Stefka AT, McMahan AE, Wright TB, Nasser MS, de Villiers WJ, Kaetzel CS: Signature biomarkers in Crohn's disease: toward a molecular classification. Mucosal Immunol 2008, 1:399-411

40. Bubici C, Papa S, Dean K, Franzoso G: Mutual cross-talk between reactive oxygen species and nuclear factor-kappa B: molecular basis and biological significance. Oncogene 2006, 25:6731-6748.

41. Madrid LV, Mayo MW, Reuther JY, Baldwin AS Jr: Akt stimulates the transactivation potential of the RelA/p65 Subunit of NF-kappa B through utilization of the Ikappa $B$ kinase and activation of the mitogenactivated protein kinase p38. J Biol Chem 2001, 276:18934-18940.

42. Deng $Y$, Ren $X$, Yang $L$, Lin $Y$, Wu X: A JNK-dependent pathway is required for TNFalpha-induced apoptosis. Cell 2003, 115:61-70.

43. Carswell EA, Old LJ, Kassel RL, Green S, Fiore N, Williamson B: An endotoxin-induced serum factor that causes necrosis of tumors. Proc Natl Acad Sci USA 1975, 72:3666-3670.

44. Balkwill F: Tumor necrosis factor or tumor promoting factor? Cytokine Growth Factor Rev 2002, 13:135-141.

45. Gordon HM, Kucera G, Salvo R, Boss JM: Tumor necrosis factor induces genes involved in inflammation, cellular and tissue repair, and metabolism in murine fibroblasts. J Immunol 1992, 148:4021-4027.

46. Yoshida S, Ono M, Shono T, Izumi H, Ishibashi T, Suzuki H, Kuwano M: Involvement of interleukin-8, vascular endothelial growth factor, and basic fibroblast growth factor in tumor necrosis factor alpha-dependent angiogenesis. Mol Cell Biol 1997, 17:4015-4023.

47. Dutta J, Fan Y, Gupta N, Fan G, Gelinas C: Current insights into the regulation of programmed cell death by NF-kappaB. Oncogene 2006, 25:6800-6816.

48. Chinery R, Brockman JA, Peeler MO, Shyr Y, Beauchamp RD, Coffey RJ: Antioxidants enhance the cytotoxicity of chemotherapeutic agents in colorectal cancer: a p53-independent induction of $\mathrm{p} 21 \mathrm{WAF} 1 / \mathrm{CIP} 1$ via C/EBPbeta. Nat Med 1997, 3:1233-1241.

49. Ravi R, Bedi A: Requirement of BAX for TRAIL/Apo2L-induced apoptosis of colorectal cancers: synergism with sulindac-mediated inhibition of $\mathrm{BCl}-\mathrm{x}(\mathrm{L})$. Cancer Res 2002, 62:1583-1587.

50. Niederberger E, Tegeder I, Vetter G, Schmidtko A, Schmidt H, Euchenhofer C, Brautigam L, Grosch S, Geisslinger G: Celecoxib loses its antiinflammatory efficacy at high doses through activation of NF-kappaB. FASEB J 2001, 15:1622-1624.

51. Smartt HJ, Elder DJ, Hicks DJ, Williams NA, Paraskeva C: Increased NFkappaB DNA binding but not transcriptional activity during apoptosis induced by the COX-2-selective inhibitor NS-398 in colorectal carcinoma cells. Br J Cancer 2003, 89:1358-1365.

52. Morise Z, Grisham MB: Molecular mechanisms involved in NSAID-induced gastropathy. J Clin Gastroenterol 1998, 27(Suppl 1):S87-S90.

53. Baron JA, Sandler RS, Bresalier RS, Quan H, Riddell R, Lanas A, Bolognese JA, Oxenius B, Horgan K, Loftus S, Morton DG: A randomized trial of rofecoxib for the chemoprevention of colorectal adenomas. Gastroenterology 2006, 131:1674-1682. 
54. Bertagnolli MM, Eagle CJ, Zauber AG, Redston M, Solomon SD, Kim K, Tang J, Rosenstein RB, Wittes J, Corle D, et al: Celecoxib for the prevention of sporadic colorectal adenomas. N Engl J Med 2006, 355:873-884.

55. Bertagnolli MM, Eagle CJ, Zauber AG, Redston M, Breazna A, Kim K, Tang J, Rosenstein RB, Umar A, Bagheri D, et al: Five-year efficacy and safety analysis of the Adenoma Prevention with Celecoxib Trial. Cancer Prev Res (Phila) 2009, 2:310-321.

56. Wallace JL, Vong L: NSAID-induced gastrointestinal damage and the design of GI-sparing NSAIDs. Curr Opin Investig Drugs 2008, 9:1151-1156.

57. Shau WY, Chen HC, Chen ST, Chou HW, Chang CH, Kuo CW, Lai MS: Risk of new acute myocardial infarction hospitalization associated with use of oral and parenteral non-steroidal anti-inflammation drugs (NSAIDs): a casecrossover study of Taiwan's National Health Insurance claims database and review of current evidence. BMC Cardiovasc Disord 2012, 12:4.

58. Sigglekow ND, Pangon L, Brummer T, Molloy M, Hawkins NJ, Ward RL, Musgrove EA, Kohonen-Corish MR: Mutated in colorectal cancer protein modulates the NFkappaB pathway. Anticancer Res 2012, 32:73-79.

59. Murayama T, Ohara Y, Obuchi M, Khabar KS, Higashi H, Mukaida N, Matsushima K: Human cytomegalovirus induces interleukin-8 production by a human monocytic cell line, THP-1, through acting concurrently on AP-1- and NF-kappaB-binding sites of the interleukin-8 gene. J Virol 1997, 71:5692-5695.

doi:10.1186/1478-811X-11-73

Cite this article as: Mladenova et al: Sulindac activates NF-KB signaling in colon cancer cells. Cell Communication and Signaling 2013 11:73.

\section{Submit your next manuscript to BioMed Central and take full advantage of:}

- Convenient online submission

- Thorough peer review

- No space constraints or color figure charges

- Immediate publication on acceptance

- Inclusion in PubMed, CAS, Scopus and Google Scholar

- Research which is freely available for redistribution 